\title{
SOFÁ NA PRAÇA: O ESPAÇO COMO ENCONTRO NO CINEMA DE JOÃO
}

\author{
SALAVIZA
}

- WENCESLAO MACHADO DE OLIVEIRA JUNIOR*

Resuma: A partir da perspectiva de cinema cama encuntra da cineasta partuguês Jaãa Salaviza, ensaiou-se aproximações entre esse estilo de fazer cinema e filmes com o pensamento da geágrafa Doreen Massey, apontando "novos passíveis" modas de lidar com a relaçãa entre imagens e geografia, enquanto propõe-se pistas para responder às perguntas: que teria esse estila de fazer cinema a nos dizer acerca de outras relações passíveis entre as imagens e a geagrafia? Haveria nesse estilo de fazer cinema potências de criação das imagens que atuariam como "geggrafias menores" capazes de provacar pequenas rasuras no pensamento geográfico em geral ou nas relações que este estabelece com as imagens, sabretuda quando estas últimas sãa significadas apenas como representaçãa espacial?

Palavras-chaves: cinema, gengrafias menores, encontra, Jaão Salaviza, Doreen Massey.

O cinema me permitiu chegar a lugares que eu não teria chegado de outra forma, lugares geográficos e lugares de intimidade.

O cinema é um dispositivo ficcional que nasce ainda antes do filme existir para que duas pessoas possam se encontrar.

O filme é um pretexto mais do que tudo. João Salaviza
As linhas e entrelinhas das duas frases que compõem a epígrafe acima ${ }^{1}$ apontam por si sós a importância do espaço na configuração do estilo de fazer cinema deste jovem artista português.

$\mathrm{O}$ presente texto ${ }^{2}$ adentra essas linhas e entrelinhas na busca de responder às perguntas que se seguem: que teria esse 
modo de fazer cinema a nos dizer acerca de outras relações possíveis entre as imagens e a geografia? Haveria nele potências de criação das imagens que atuariam como geografias menores capazes de provocar pequenas rasuras no pensamento geográfico em geral ou nas relações que este estabelece com as imagens, sobretudo quando estas últimas são significadas apenas como representação espacial?

A expressão geografias menores é tributária de nosso contágio com alguns conceitos da filosofia da diferença, sobretudo os conceitos de minoridade, resistência e fabulação, provenientes de diversas obras de Gilles Deleuze e Félix Guattari. [...] Geografias menores são forças minoritárias que se agitam no interior da Geografia maior. Não existem como formas acabadas, mas como potência de devir naquilo que já está estabelecido. Seriam, portanto, todas aquelas forças (conceituais, formais, temáticas, metodológicas etc) que operam rupturas, fraturas e esburacamentos, oscilações, dúvidas e incorporações novas naquilo que antes já era Geografia. São antes aquilo que promove outras conexões e possibilidades, não necessariamente rompimentos ou negações; ampliam as margens em que o pensamento ESPAÇO E CULTURA, UERJ, RJ, N. 39, P.81-102,JAN./JUN. DE 2016 http://www.e-publicacoes.verj.br/index.php/espacoecultura/ geográfico se dá, abrindo nele novos possíveis. (Oliveira Jr, 2014, p. 487)

Um primeiro novo possível ${ }^{3}$ que será apontado ao longo desse ensaio já nos chega das falas desse cineasta no deslocamento que propõe das imagens cinematográficas para paragens não representacionais na medida mesma que concebe o real e a realidade como algo não abarcável, como algo que, sobretudo, escapa das tentativas de representação. João Salaviza diz que todo realizador de cinema pensa em "como é que o espaço se materializa dentro de um quadrado ou de um rectângulo quando uma imagem existe" 4 , salientando que prefere pensar essa materialização como apropriação e não representação. Essa apropriação não seria daquilo que preexiste ao cinema, mas sim da tensão que se efetivaria pela e na imagem quando há o encontro do cinema com um lugar: "eu acho que no cinema, pelo menos naquele cinema em que eu acredito, tem que existir uma espécie de tensão muito clara e muito visível entre as pessoas, a presença humana e o espaço ou a paisagem em seu redor" ${ }^{5}$, e completa dizendo gostar muito "que essa tensão se materialize, que vire uma espécie de limitação que o cinema tem, uma impossibilidade de fixar o presente"6. 
Um segundo novo possível que será apontado aqui diz respeito às potencialidades da aproximação entre o pensamento de João Salaviza acerca do cinema e o pensamento de Doreen Massey acerca do espaço. Num breve resumo, para essa geógrafa, uma das potencialidades do espaço é "a justaposição circunstancial de trajetórias previamente não conectadas [criadora de um] estar juntos [...] nãocoordenado” (p.143). O espaço, portanto, "não é, de forma alguma, uma superfície" (p.160), mas sim "a esfera da coexistência de uma multiplicidade de trajetórias” (p.100) humanas e não-humanas, "uma simultaneidade de estórias-até-agora” (p.29) que "envolve contato e alguma forma de negociação social” (p.143). O espaço "é uma eventualidade" (p.89), "um produto contínuo de interconexões e nãoconexões $[\ldots]$ sempre inacabado e aberto" (p.160), estando, portanto, "sempre em construção" (p.29). “O espaço é o entrelaçamento de trajetórias em curso, das quais algo novo pode emergir. $\mathrm{O}$ movimento, o encontro e a construção das relações entre as trajetórias levam tempo" (p. 138). "O espaço como devires coetâneos" (p.267) "implica o inesperado" (p.165) (Massey, 2008).

Inicio a referida aproximação entre os dois pensamentos acerca do espaço com uma pergunta: teria a tensão apontada por
Salaviza alguma proximidade com as desarticulações entre trajetórias destacadas por Massey (2008) em sua conceituação do espaço como constelação de trajetórias heterogêneas, como encontro de histórias-até-agora? Penso que sim, uma vez que ambas, tensão e desarticulação, apontam para aquilo que já compõe as relações espaciais mas que aind $a^{7}$ não é sensível ou passível de fixar o presente. Algo, portanto, que encontra-se entre as trajetórias coetâneas ou copresentes, a um só tempo articuladas e desarticuladas, que configuram o espaçolugar8 como em devir, aberto a tornar-se outro justamente em meio às negociações inevitáveis que a heterogeneidade de trajetórias, em meio à tensão "entre as pessoas, a presença humana e o espaço ou a paisagem em seu redor".

No mesmo sentido apontado pela aproximação conceitual destacada acima, poderíamos aproximar a importância daquilo que não é fixável como presente com a importância de filmar o real enquanto algo que não se deixa capturar, como algo que, como o cinema para Salaviza, está sempre em fluxo:

o plano cinematográfico é um espaço de passagem, acima de tudo [...] é um sítio de fluxo, de passagem de imagens e de sons, e eu acredito num 
cinema permeável à realidade [e] há sempre muito mais realidade do que aquela que um filme consegue filmar. ${ }^{9}$

$\mathrm{Na}$ esteira de muitos cineastas e pensadores do final do século $\mathrm{XX}^{10}$, podemos chamar de real aquilo que, a um só tempo, compõe e excede à realidade, algo expresso por João Salaviza ao dizer que "há sempre muito mais realidade". Em todas as suas falas, esse cineasta aponta para a impossibilidade da imagem representar o real ao mesmo tempo que aposta no cinema - na imagem - como algo permeável à realidade, portanto, num cinema onde o real vem se expressar, onde o real encontra passagens para tornar-se sensível não só naquilo que já conhecemos, mas também e sobretudo, naquilo que encontrou, enfim, linguagem para ser expresso em imagens e sons justamente por ter forçado a linguagem do cinema a ser outra, a abrir-se - como espaço de passagem - para esse real, essa realidade que, antes do filme, permanecia insensível, embora já constituísse o real como aquilo que excede a realidade ${ }^{11}$.

Ao pretender um cinema permeável à realidade e conceber a realidade como constituída de um excesso que não pode ser capturado nela mesma, o estilo $^{12}$ de fazer cinema de João Salaviza não se pauta na representação dessa realidade, mas sim na criação de artifícios que forçarão o cinema a inventar linguagem a cada encontro que o estiloprocesso de produção de um filme implica para esse artista, de modo a encontrar passagens através da linguagem no cinema que tornem sensível no filme o sutil e silencioso devir do real que ali veio a constituir-se. Nem linguagem, nem lugar, nem realidade pré-existem ao encontro, mas gestam-se nele... como tensão, negociação... enfim, como devir ${ }^{13}$.

Interessante notar que Doreen Massey pensa o espaço como devir justamente por conceitua-lo como encontro de trajetórias humanas e não humanas, reforçando as aproximações que busco fazer entre os conceitos dessa geógrafa e o cinema de João Salaviza.

Geógrafa e cineasta afirmam o encontro que não se dá apenas entre humanos, e buscam justamente destacar o não humano presente nos lugares - no espaço - que, a um só tempo, extrapola e afirma o humano, afeta-o enquanto o constitui, fazendo, portanto, imanente a ele.

É nesse sentido que entendo as seguintes frases do cineasta:

Nos meus filmes eu gosto muito de sentir que a presença da câmara está ali para observar as coisas a 
acontecerem, mas não necessariamente numa lógica que seja puramente narrativa no sentido clássico da coisa, em que há uma personagem que vai do ponto $\mathrm{A}$ ao ponto B e a voz da narração que de algum modo acompanha a movimentação dessa personagem; há muitos momentos que me interessam em que simplesmente as personagens desaparecem e o espaço continua a reflectir. ${ }^{14}$

Neste trecho, nota-se que o estilo de fazer cinema de Salaviza opera uma "restrição" no preenchimento do quadro fílmico somente pelo homem, pelos corpos humanos, e, ao mesmo tempo, indica uma "disposição" para deixar a câmera observar, sendo esse observar ${ }^{15}$ entendido como uma "restrição" da narrativa clássica em que se acompanha a história humana a se desenrolar na tela. Um filme de João Salaviza se faz, portanto, não somente em torno de uma história, mas compõe-se também de "deslocamentos puros", deambulações aleatórias onde o real - a "vida íntima" que emerge nos encontros inusitados entre corpos e lugares - poderá vir a manifestar-se mais intensamente que na história ficcional. Deslocamentos e deambulações, portanto, cujos sentidos escapam da história e cujas direções escapam do caminho que vai do ponto $\mathrm{A}$ ao ponto $\mathrm{B}$.

$\mathrm{O}$ destaque dado às palavras somente e também no parágrafo anterior deve-se ao fato de que essa predominância do "espaço que reflete" em certos momentos dos filmes de Salaviza se dá por um artifício estabelecido na própria história que está sendo contada. Em outras palavras, a história é importante, mas deve ser fácil, de entendimento quase imediato em seus traços gerais. É isso que permitirá ao espectador desprender-se da história e deixar-se levar nos desvios "não-narrativos" por lugares sem a presença humana e por cenários pouco atinentes ao sentido geral da história, bem como permite que o próprio diretor se entregue ao encontro entre cinema $\mathrm{e}$ cidade de maneira mais aberta. Nas palavras dele próprio: "O ponto de partida pode ser qualquer coisa de muito simples que apenas me empurra a uma viagem onde eu vou encontrar as coisas que me interessam, pelas quais me apaixono enquanto estou a filmar." 16

Ao final do ensaio voltaremos a essa história-ficção fácil como dispositivo para trazer mais intensamente a realidadevida para o filme através da deriva espacial dos corpos humanos pela cidade, uma vez que é nessa deriva onde, talvez, a 
intimidade poderá vir a emergir e impregnar o filme.

Em uma expressão utilizada pelo próprio cineasta para falar de práticas sociais nas periferias de Lisboa, colocar o sofá na rua

é a presença da intimidade... é o avesso do conflito entre o espaço público e privado que é ter o elemento completamente doméstico dentro do espaço público [e], como uma extensão da vida doméstica para o exterior da casa, é um gesto profundamente político e antiideológico na medida que se reafirma um direito à ocupação da cidade pelas pessoas para viverem suas vidas não da forma como nos dizem para vivermos, mas da forma como bem entendermos. ${ }^{17}$

Para João Salaviza, portanto, os lugares da intimidade não se opõem aos lugares geográficos, mas sim se configuram e se co-constituem no espaço público.

\section{Um olhar que confronta o espaço?}

Iniciemos essa aproximação da intimidade que se dá no espaço público pelo sentido humano mais voltado ao mundo externo: olhar. Pensemos no olhar de cada um dos personagens ao final de cada um dos três curtas da "trilogia" de Salaviza, lembrando, a partir de Almeida (1994), que os filmes constituem-se como uma nova oralidade e, como tal, fazem com que tudo seja mantido em suspenso até o último momento, pois até o final é possível desdizer tudo o que havia sido dito-mostrado; desta maneira, pode-se dizer que a última imagem de um filme dobra-se sobre todas as demais, não só porque as arrasta para fora do filme, mas também porque dá-lhes o sentido, não mais passível de ser alterado.

Apesar das enormes diferenças, há algo em comum no olhar dos personagens ao final de todos os três curtas. A cena que finaliza quaisquer deles mostra os personagens a olhar para fora do quadro, para algo não visível aos espectadores, mas presente no extracampo espacial fílmico. Em Arena (2009), Mauro olha para o alto invisível, deitado sobre o topo de uma construção; em Cerro Negro (2011), Allison olha para o fundo de cena negroazulado, em pé diante da janela de dentro da prisão; em Rafa (2012), Rafa olha para a lateral do quadro, em pé em frente à delegacia. Se nos dois primeiros filmes da "trilogia" não vemos os olhos dos protagonistas ao final - não nos sendo possível dizer se estão abertos ou fechados -, os olhos de Rafa estão quase 
arregalados quando há o corte que finaliza o filme. É pelos olhos deste último que prefiro pensar que Mauro e Allison também estão de olhos abertos a mirar o que (não) há no céu azul ou na noite escura, respectivamente. Ainda que cada um deles mire em uma direção - para o alto, para o fundo e para o lado - pode-se dizer que olham para o entorno onde estão: o céu e as nuvens num dia de sol, o horizonte restrito visto da janela de um presídio ou os muitos elementos do centro de uma cidade.

Os três jovens personagens tem, portanto, o olhar voltado para fora; para fora do quadro sim, mas sobretudo para fora de si. Essa ideia fica mais nítida quando vemos o corte seco que finaliza o último dos curtas, Rafa, exatamente no momento em que o personagem levanta os olhos do bebê que segura no colo - e que o fazia olhar para baixo e para algo vinculado à si pela família - lançando olhar quase arregalado para a frente, para o lado da cidade que nós, como espectadores, não vemos: um olhar para o desconhecido que o afeta vindo de fora, para o desconhecido onde procura pistas para respostas às muitas perguntas que aquele olhar faz.

Um olhar que se volta para a realidade, para a $\operatorname{cidade}^{18}$, para o que constitui o lugar onde está o personagem.
Um olhar que busca, que pensa através daquilo que lhe chega de fora, que pergunta mais que responde, ou, nas palavras de Salaviza, "um olhar que confronta”. Confronta o quê? Nas diversas entrevistas desse diretor, parece que esse confronto é com a instituição, com aquilo que aprisiona os corpos em certos gestos e ações estabelecidos na cultura instituída, esta sendo o que impede a intimidade de vir a tona. Intimidade entendida como singularidade efetivada por um corpo, mas não um corpo em si mesmo, mas em suas conexões diversas com o que lhe afeta em suas articulações e desarticulações com as demais trajetórias que compõem o lugar onde esse corpo vive e se constitui singular porque afetado pela multiplicidade de forças provenientes de trajetórias heterogêneas: singular porque coletivo, ou melhor, múltiplo, heterogeneamente afetado. A intimidade, enquanto singularidade, se efetiva, portanto, no encontro, como encontro.

Se o olhar para fora do quadro pode ser interpretado como uma busca por algo que encontra-se para além do cinema e do filme - a realidade que excede a capacidade do cinema mostrar -, o olhar para fora de si radicaliza a perspectiva de uma busca no espaço, enquanto heterogêneo e aberto, de pistas para respostas que não foram encontradas nos 
próprios pensamentos e ações. Em todos os três curtas, acompanhamos jovens personagens a agir segundo o que acreditam ser a melhor forma de alcançar o que desejam: a violência de Mauro para obter seu dinheiro de volta, a insistência de Allison para falar com o filho, a dedicação de Rafa em voltar várias vezes à delegacia para buscar a mãe. Eles se cansam de tentar e, ao final, estão esgotados. Para Gilles Deleuze

o esgotado é muito mais que o cansado. $[\ldots] \mathrm{O}$ cansado não dispõe mais de qualquer possibilidade (subjetiva) - não pode, portanto, realizar a mínima possibilidade (objetiva). Mas esta permanece, porque nunca se realiza todo $\mathrm{o}$ possível; ele é até mesmo criado à medida que é realizado. O cansado apenas esgotou a realização, enquanto o esgotado esgota todo o possível. O cansado não pode mais realizar, mas o esgotado não pode mais possibilitar. Não há mais possível: um espinosismo obstinado. Ele esgotaria o possível porque está esgotado ou estaria esgotado porque esgotou o possível? Ele se esgota ao esgotar o possível, e inversamente. Esgota o que não se realiza no possível. [...] Mas a realização do possível procede sempre por exclusão, pois ela supõe preferências e objetivos que variam, sempre substituindo os precedentes. São essas variações, essas substituições, todas essas disjunções exclusivas $[\ldots .$.$] que acabam cansando.$ Bem diferente é o esgotamento: combina-se o conjunto das variáveis de uma situação, com a condição de renunciar a qualquer ordem de preferência e a qualquer objetivo, a qualquer significação. (Deleuze, 2010, p. $67-8)$

É nesse cansaço de agir segundo o já conhecido que o esgotamento retira sua força de invenção e experimentação e, por isso, enquanto esgotado "não se é passivo: está-se em atividade, mas para nada. Estava-se cansado de alguma coisa, mas esgotado de nada" (Deleuze, 2010, p.69). $\mathrm{O}$ nada aqui referindo-se à ausência de preferências ou objetivos, portanto, a um esvaziamento simultâneo a uma abertura. Ao final dos três curtas de Salaviza estamos diante de corpos esgotados, muito mais que cansados. Ao pensar dessa maneira, considero esses personagens a lançar perguntas ao mundo com aquele olhar esvaziado e aberto, um olhar que não lança perguntas formuladas, específicas, objetivas, mas que lança-se, arregalado, como pergunta ao mundo ${ }^{19}$, interpelando as variadas trajetórias de seu entorno acerca de que outras forças poderiam ser gestadas se e quando 
efetivarem-se outros tipos de encontros entre eles, corpos humanos, e algum ou alguns dos corpos humanos e não humanos que configuram aquele lugar, tomado como copresença, ou aquele espaço, tomado como coetaneidade (Massey, 2008).

O esgotado não vai buscar novas forças naquilo que já conhece, porque já esgotou essa busca; sua busca agora se volta para experimentações com e no desconhecido, naquilo que já constitui o seu mundo mas que ainda não lhe é sensível, não se fez encontro singular, não configura, ainda, alguma intimidade. $\mathrm{O}$ esgotado volta-se para o impossível aquilo que vai além dos possíveis já previsíveis e realizados - onde novos possiveis podem vir a efetivar-se.

Retomando aos três curtas de João Salaviza, o percurso espacial que acompanhamos em todos vai de um lugar privado a um lugar público. De lugares pouco extensos e com paredes ao fundo, acompanhamos personagens e percursos que se lançam em extensões mais amplas e com paredes existentes ao longe ou atravessadas por janelas. Mauro inicia Arena no apartamento onde vive só e finaliza no topo de um prédio, após percorrer a esmo - à procura de meninos que ele não sabe onde estão - corredores, passarelas e rampas dos prédios de um grande conjunto habitacional da periferia de Lisboa. Anajara inicia Cerro Negro em casa com o filho e, após atravessar a cidade, na prisão abraça Allison e deixa o (percurso do) filme ser continuado por esse último que o finaliza diante da janela de sua cela a mirar para fora, para longe da televisão ligada e dos desenhos de seu filho. Rafa inicia o filme homônimo no apartamento onde vive com a família e, após andar por Lisboa num misto de movimento pendular e zig-zag, finaliza o filme num largo aberto no centro desta cidade.

É nessa perspectiva que entendo a aposta na intimidade que atravessa todo o cinema de João Salaviza como também uma aposta no espaço público. Aposta essa que me levou a intitular esse texto de "sofá na praça" como maneira de radicalizar duas coisas. A primeira delas seria vinculada às lembranças, reiteradamente presentes nas entrevistas desse cineasta, dos bairros de sua infância onde as pessoas colocavam, e nas periferias ainda colocam, cadeiras e sofás na calçada para ficarem a observar o que ocorria, e ocorre, na rua em frente às suas casas. A segunda das coisas que busco radicalizar nesta expressão - imagem? - é o deslocamento que o estilo de fazer cinema de Salaviza realiza nesse gesto popular ao fazer o corpo sentado no sofá 
deambular pela cidade, aleatoriamente, $a o$ encontro, mas também de encontro, com um espaço público muito mais amplo e desconhecido que a frente de suas casas. Notar que é o corpo, e não um olhar sem corpo, que é arrastado pela cidade afora, uma vez que o deslocamento proposto no estilo desse diretor ao propor uma apropriação da realidade nega um olhar exterior sobre o mundo - aquele olhar que representa o mundo e é solicitado pela televisão diante do sofá -, na medida mesma que seus filmes exibem corpos junto ao mundo, apropriando-se dele nos encontros, encontros nos quais se constituem, se descobrem e se afirmam no e através do espaço público, como fica explícito quando o cineasta diz que colocar o sofá na rua (ou na praça) é "uma extensão da vida doméstica para o exterior da casa. E esse é um gesto profundamente político e anti-ideológico na medida que se reafirma um direito à ocupação da cidade pelas pessoas para viverem suas vidas não da forma como nos dizem para vivermos, mas da forma como bem entendermos". ${ }^{20}$ É nesse sentido que os corpos em movimento pela cidade nos filmes de Salaviza são, também e ao mesmo tempo, os corpos sentados num sofá levado à praça pública, sendo esta tomada como a forma urbana - o lugar para onde converge a maior ESPAÇO E CULTURA, UERJ, RJ, N. 39, P.81-102,JAN./JUN. DE 2016 http://www.e-publicacoes.verj.br/index.php/espacoecultura/ heterogeneidade de trajetórias que constitui uma cidade ${ }^{21}$, onde o aleatório e o imprevisível se fazem mais presentes e intensos como forças para a criação de outros devires espaciais.

Portanto, nem aos personagens, nem ao diretor - como está explícito na epígrafe desse texto -, é dada a possibilidade desse olhar externo ao mundo público, uma vez que é justamente nesse fora do mundo privado que a intimidade resiste e insiste em compor os corpos como formas singulares - íntimas - de vida justamente quando escapam das instituições que buscam conter os corpos em certos padrões e modelos que aprisionam e impedem o vazamento da intimidade, sobretudo nos espaços privados ou privatizados por alguma instituição específica.

\section{A realidade nos corpos: a intimidade como sobra}

Salaviza diz que num set de filmagem

estamos numa espécie de jogo de cena que nos protege a todos, mas mesmo assim há alguns vestígios de intimidade que transbordam pra lá destas proteções todas e que escrevem qualquer coisa sobre os personagens 
no espaço e no tempo. E eu acho que são essas micro-ações e momentos muito precisos que dizem qualquer coisa sobre os tipos que estou a filmar. E que são coisas que me escapam também porque não são propostas por mim, e é aí que eu acho que meu trabalho enquanto realizador é criar condições para que essas coisas venham ao de cima, emerjam, façam emergir. Meu trabalho no cinema é iluminar, indicar esses pequenos momentos, criar condições para que haja luz sobre esses pequenos momentos... de intimidade. Mas que são deles, isso tenho a certeza absoluta. ${ }^{2}$

Esse deles referindo-se a um só tempo ao corpo - o qual já está numa metamorfose, numa zona de indistinção entre pessoa e personagem - e ao encontro singular entre esse corpo já indistinto e as demais trajetórias presentes no lugar público onde esse corpo foi ter em seus deslocamentos puros, suas deambulações para nada que abrem esse corpo para encontros com o imprevisto e imprevisível onde algo íntimo pode vir "ao de cima", que se revelam em momentos "muito precisos e muito ínfimos", no dizer do cineasta. O ínfimo movimento que revela as marcas da história pessoal e também da história social do lugar onde aquele encontro se deu, fazendo com que seja esse ínfimo movimento que efetiva uma singularidade no gesto-encontro: a intimidade.

É possível reconhecer esse amálgama entre público e privado, entre espaço público e intimidade em outras falas de João Salaviza acerca de suas escolhas:

parece-me muito claro que o miúdo do Rafa sentar-se naquele espaço [praça] onde os miúdos do centro da cidade estão a andar de skate e ele mal conseguir estabelecer uma relação com eles, e sentar-se dentro daquele espaço, mas a parte, a olhar para os miúdos a andar de skate, e com uma delicadeza quase... acho lindíssima a forma como ele rouba aquela carteira porque é de uma precisão e de uma candura ao mesmo tempo... como o gesto de roubar pode ser bonito também... e filmar isso quase como uma pequena obra de arte, como ele faz ali, como as mãos roubam aquela carteira ou, como no fim do filme, como ele protege o bebé; de repente, naquele corpo bruto e rude também há vestígios de uma delicadeza enorme, e acho que isso é muito revelador. Acho que fazer um filme também é estar atento a esses pequenos gestos em que o corpo se tenta esconder e não consegue. ${ }^{23}$ 
Neste trecho da entrevista o cineasta destaca um dos lugares encontrados por Rafa em sua deambulação pelo centro de Lisboa. $O$ personagem chega a um espaço público que lhe é novo, onde as trajetórias copresentes não se articulam à sua e o colocam a parte. É desse lugar a parte, desarticulado, que busca estabelecer alguma articulação, algum encontro com outra trajetória que amplie sua potência de agir ali. Neste caso, o encontro se deu com a mochila, desencadeado pelo gesto previsto no roteiro ficcional, mas que, de repente, trouxe ao filme algo mais que o gesto de roubar, trouxe um gesto singular de como roubar, trouxe os vestígios de uma delicadeza enorme num corpo bruto e rude. Trouxe, de repente, a intimidade a tona como "fagulha do real" que emergiu justamente na zona não determinada pelo roteiro, naquilo que escapa do previsível e instituído no momento em que se experimenta a indistinção entre personagem e pessoa ${ }^{24}$.

Ao observar com a câmera, Salaviza busca captar o que escapa do corpo que desvia-se do gesto roteirizado. É justamente no que sobra para além da ficção, mas que foi acionado por ela, onde aparece o traço ínfimo, o movimento preciso, aquele gesto íntimo do corpo, aquele que não foi pensado, mas que se fez notar quando, livre do si mesmo, o personagem deixou vazar ali traços impregnados na pessoa; personagem e pessoa ali já indistintos pelo dispositivo proposto nesse estilo de fazer do cinema que, ao fragilizar a história contada tornase mais permeável à realidade que atravessa os corpos das pessoas e que escapa deles - como sobra - quando estes encontram-se com o inesperado do novo gesto tributário do cinema e efetivado num lugar inesperado, o qual força o corpo a encontrar outros modos de negociar relações em meio às tensões desse encontro no e com o espaço heterogêneo.

Por isso mesmo que toco muito nesta ideia da intimidade: como mesmo num espaço público os gestos e as ações e as palavras também podem remeter para zonas de intimidade. Portanto, para além da geografia do espaço, há uma zona de afeto que é essa mesma onde eu gosto de sonhar que é possível chegar com a câmera de filmar. ${ }^{25}$

Em meu argumento não seria mesmo num espaço público, mas sim justo num espaço público, porque é nele que o heterogêneo afeta o corpo de maneira mais imprevista e tem, portanto, maior potência 
para fazer vazar a intimidade aprisionada no corpo pelo institucionalizado. É por isso que o percurso dos filmes e dos personagens vai do mais privado ao mais público e não necessariamente do mais fechado para o mais aberto. A prisão, por exemplo, onde termina Cerro Negro é mais fechada, mas é mais pública que a casa. Em outras palavras, para que a proposta de apropriação da realidade como intimidade ${ }^{26}$ se realize no filme, o dispositivo - o estilo - cinematográfico de João Salaviza precisa forçar os corpos-personagens à deriva no espaço público, força-los a ir ao encontro e de encontro ao heterogêneo imprevisível para que algo de íntimo neles aflore, emerja.

É preciso forçar a deriva, como puro deslocamento para nada, não somente dos personagens, mas também do espectador: é nesse sentido que a ficção frágil - uma história fácil - atua como dispositivo do cinema para que o filme venha a existir como encontro, podendo a intimidade que emerge dele e é gravada no filme ser tomada como o índice de permeabilidade do real alcançado em cada projeto cinematográfico deste cineasta.

\footnotetext{
Uma história fácil e um corpo à deriva
}

Ao falar do curta Rafa (2012), Salaviza diz: "o dispositivo ficcional que eu encontro é um pretexto para poder ir atrás desse miúdo que quero filmar... e voltar aos espaços que também percorri na adolescência no centro de Lisboa”. ${ }^{27}$ Ir atrás tem múltiplos sentidos aqui. Dois deles trago a esse texto. O primeiro é o de ir em busca de um corpo jovem na cidade de Lisboa onde o personagem ficcional imaginado venha a se "incorporar" de tal forma que torne-se indiscernível da pessoa $^{28}$, numa metamorfose de ambos, personagem e pessoa, que faz emergir algumas das principais marcas e potências deste estilo de fazer cinema no qual a ficção - o roteiro, a história frágil - é um artifício, sobretudo, para o encontro com certas pessoas e certos lugares geográficos onde "fragmentos imperceptíveis do real", talvez, venham a emergir e fazerem-se sensíveis através do filme: "o trabalho do realizador é andar atrás desses respigos" ${ }^{29}$. É nesse sentido que os personagens de seus filmes não são tipos sociais, mas pessoas singulares, únicas, cuja principal característica é não saber o que fazer diante do mundo à sua volta, uma vez que esgotaram todas as possibilidades de ação que conheciam, inclusive a violência. Em seus filmes os personagens terminam “olhando" pro mundo amplo, sem foco fixo - pro céu, em Arena e Cerro Negro, pra 
cidade à volta, em Rafa-, mas é como se esse "olhar" fosse uma espécie de "não ver" porque se faz de uma busca, de uma forte mistura das paisagens interiores com as exteriores, algo que faz oscilar tanto os personagens quanto os espectadores, pelo menos aqueles que se identificaram com os personagens e "olham" pro mundo a partir deles, ou melhor, através deles. O interessante é que passamos a olhar mais de perto, mesmo de "dentro" deles, justo quando os personagens se distanciam do espaço interior-privado onde eles vivem da moradia, seja a casa ou a cela da prisão. Isso se daria, talvez, porque as perguntas íntimas (as mais intensas!) que estes personagens fazem não são para eles próprios - para aquilo que os povoa no interior privado -, mas sim para o mundo - para aquilo que os está povoando no exterior público -, fazendo com que a intimidade deles se dê - se faça existir naquele corpo e se revele ao espectador justamente no espaço público.

O segundo dos sentidos de ir atrás que trago aqui é o de observar, numa acepção desse verbo muito cara a João Salaviza: observar está voltado tanto ao acompanhamento dos movimentos do corpo jovem em deriva pela cidade quanto à "possibilidade de observar enquanto me movimento"30. Destaquei o enquanto porque é nele que me parece residir a distinção radical que este artista faz entre um cinema que observa o mundo de fora e outro que observa de dentro, fazendo-se ele próprio movimento do e com o mundo. Movimento de observar que é também ir atrás da memória como algo que é mote de acesso ao íntimo pessoal (das lembranças de juventude) para gestar mais um tipo de encontro com o "aleatório espacial", uma vez que o retorno do cineasta aos espaços que percorreu na adolescência se faz, sobretudo, de rupturas com o vivido por ele, sendo a cidade outra, constituindo-se hoje de uma constelação de trajetórias bastante distinta daquelas que articulavam o vivido quinze anos atrás. Essa diferença faz incidir algo de aleatório no que o cineasta encontrará naqueles espaços da adolescência e fará com que, no momento de filmagem nestes lugares onde João Salaviza esteve anos antes, não seja possível repetir as ações dele, exigindo decisões a serem tomadas pela equipe, aí incluídos os atores. Decisões estas que, por serem tomadas vinculadas à realidade que ali está, efetuarão fissuras no roteiro pensado a partir das lembranças, tornando-o mais permeável à vida que se efetiva naquele lugar hoje e, justo por isso, tem maior potência para fazer emergir algo da vida e dos corpos dos atores no encontro com as trajetórias heterogêneas que configuram aquele lugar, algumas das 
quais serão arrastadas para o filme na medida mesma que afetarem a equipe de filmagem para fazer a cena de tal ou qual maneira.

$\mathrm{Na}$ zona indistinta entre diversas temporalidades e espacialidades que se constitui em seu estilo de fazer cinema e filmes, pode-se dizer que esse cineasta busca escapar do cinema que observa de fora o mundo - e, assim, representa-lo como realidade neutra e objetiva - ao mesmo tempo que busca abrir passagens para o que emerge dos e nos encontros promovidos por ele, cinema, enquanto parte do próprio mundo - e, assim, tornalo permeável à realidade como devir, permeável ao real. Ao buscar desencadear encontros através do cinema, o que parece agitar-se como principal força no processo de criação de Salaviza são estratégias para perder-se nesses encontros, para deixar-se levar no espaço e no filme por aquilo que constitui o real como algo imperceptível, desafiando o cinema a inventar maneiras criar linguagem - que, talvez, tornem perceptíveis alguns fragmentos desse real.

Em Cerro Negro interessou-me filmar a ideia da ausência, ou seja, de como é que os espaços e o nosso cotidiano podem estar impregnados pela presença de alguém que não está fisicamente presente. E mais uma vez encontrei um dispositivo ficcional [...] pra poder depois encontrar as coisas intrínsecas das duas pessoas que filmei. Esse dispositivo é muito simples, uma mulher tem um marido que está preso; e assim é uma proposta de ficção ou uma proposta de cinema, se calhar a única ideia de cinema nesse filme, quando todo o resto é tentar filmar a intimidade das duas pessoas que filmei. ${ }^{31}$

Nesse sentido, o cinema seria esse dispositivo ficcional simples para, depois, se aproximar da realidade e, desdobrado o cinema em forma de filme, seria o pretexto para encontrar e encontrar-se com pessoas e lugares onde algum fragmento imperceptível do real pode vir a se deixar observar pela câmera e se impregnar nas imagens e sons. Pode-se dizer que esse imperceptível perseguido por João Salaviza é o que ele denomina intimidade.

A intimidade, conforme já foi apontado em outras partes acima, é entendida por ele como aquela característica que há num corpo humano que ainda não foi totalmente aprisionada pelas normas e formas institucionalizadoras de como devemos viver: ela é uma força politicamente potente para nos mostrar a vida como variedade e variação, sendo, portanto, 
potente na criação de novos possíveis modos de estar no mundo. É certo que por mais opressivas que sejam nossas instituições, todo corpo mantém alguma intimidade. Mas seriam, segundo esse cineasta, os corpos que estão à margem da sociedade burguesa de consumo e os que estão em franco processo de transformação, como os jovens, os menos afetados pelas normas e padrões, onde algo mais cru estaria pulsando e, por isso, interessam mais a ele, uma vez que nesses corpos há uma camada mais densa e intensa de intimidade que pode vir a aparecer - vir ao de cima, nas palavras de Salaviza - ao longo da realização do filme, antes de ser novamente submersa sob a necessidade de agir conforme as normas e formas institucionalizadas.

Um dos aspectos do dispositivo ficcional efetivado pelo estilo desse diretor atua exatamente aí: fazer esse corpo onde existe uma camada mais densa e intensa de intimidade entrar em contato com lugares por ele desconhecidos, de modo a dificultar ou mesmo impedir que o contexto social e espacial conhecido aja sobre esse corpo, forçando-o às normas, aos padrões, aos hábitos. É justo para criar possibilidades para captar a intimidade que é necessário fazer emergir um gesto singular - e inesperado - que surge em um corpo no encontro com o lugar geográfico, encontro promovido pela ficção proveniente do cinema entre esse corpo e os elementos do espaço público, apostando que algo de novo - de íntimo pode advir daí, desse e nesse encontro.

Pode-se pensar, então, a intimidade menos como um dado ou uma característica e mais como um atravessamento que emerge em um corpo humano não quando esse corpo está onde mora ou circula habitualmente, mas sim, como algo que pode vir a atravessar esse corpo e vir à tona quando ele é forçado a deixar seus lugares habituais e encontrarse com outros corpos e objetos e fluxos em contextos distintos; quando, em outras palavras que retomam os conceitos de Doreen Massey, esse corpo é forçado a encontrar-se com outras trajetórias copresentes no lugar onde chegou em sua deriva pelo espaço público.

Pode-se pensar também que esse encontro promovido pelo cinema também faz com que o lugar - e o espaço público seja outro, uma vez que é habitado de outras maneiras, abrindo nele novos possíveis ali instaurados no e com o encontro entre cinema e espaço. É nesse sentido que agitam-se geografias menores nos estilos artísticos que abrem-se para o espaço como agente potente para fazer emergir outros encontros onde o vivido e vívido dos lugares podem, talvez, 
agenciados pelo cinema, forjar - forçar? outras conexões e possibilidades para o pensamento geográfico ${ }^{32}$. É justo esse caráter vívido do espaço que, segundo Doreen Massey, tem potencialidade para fazer um lugar devir outro desde dentro dele mesmo, em variações e metamorfoses gestadas nas e pelas negociações entre as trajetórias que ali se encontram copresentes, sendo que os devires espaciais emergem sobretudo nas tensões e negociações que se efetivam entre trajetórias desarticuladas, as quais gestam novas articulações e desarticulações, mantendo o espaço como algo em aberto onde a política - pensada como negociação entre trajetórias heterogêneas - se faz necessária (Massey, 1999; 2008).

Nesse sentido o caráter vívido de um lugar pode ser entendido como algo que extrapola o vivido, uma vez que o vívido remete exatamente para aquilo que ainda não é, que aponta para devires ainda imprevistos e insensíveis na realidade vivida, mas já pulsantes, agindo como força imperceptível - porque desarticulada? - nas microfissuras abertas no que está articulado. Microfissuras que podem vir a tornarem-se sensíveis quando o cinema aporta num determinado lugar sem a pretensão de mostra-lo como ele já é, mas com a disposição de inventar ali outras maneiras de viver nos e os encontros em que, de repente, nos apaixonamos por algo... que, enfim, nos escapa.

\section{NOTAS}

* Graduado em Geografia (UFJF), Mestre e Doutor em Educação (UNICAMP). Professor no Departamento de Educação, Conhecimento, Linguagem e Arte e pesquisador do Laboratório de Estudos Audiovisuais OLHO, ambos da Faculdade de Educação/Unicamp.

1 Frases retiradas da transcrição de entrevista concedida a mim por João Salaviza, em 2015, numa tasquinha de Lisboa. Tendo em vista a quantidade e qualidade das falas do cineasta nessa entrevista, bem como em outra, concedida por ele à pesquisadora Helena Pires, da Universidade do Minho, em 2014, sobre as relações entre espaçopaisagem e cinema em seus filmes, decidi realizar a escrita desse texto quase que exclusivamente num diálogo com essas falas, nas quais ele reflete acerca da importância do espaço para a configuração de seu estilo de fazer cinema.

${ }^{2}$ Este ensaio teve uma primeira versão publicada nos anais do II Simpósio Internacional Geografia, Literatura e Arte e é um desdobramento da pesquisa As geografias menores em obras de vídeo de três artistas contemporâneos, realizada como pósdoutoramento na Universidade do Minho (Portugal) e financiada pelo $\mathrm{CNPq}$ (Brasil).

${ }^{3}$ Assumo aqui que, a partir de diversos escritos de Gilles Deleuze, um novo possivel não é algo previsível e portanto não se faz no campo das possibilidades ou probabilidades aventadas. Nesse sentido um novo possível é algo arrancado ao Impossível, algo que, esgotados os possíveis, se inventa. 
4. Trecho de entrevista concedida à pesquisadora Helena Pires, em 2014, numa mesa de mercado público de Lisboa, a quem agradeço a gentileza de ceder-me a transcrição como material de pesquisa.

5 Trecho de entrevista concedida à pesquisadora Helena Pires, em 2014, numa mesa de mercado público de Lisboa. O destaque é meu.

6 Trecho de entrevista concedida à pesquisadora Helena Pires, em 2014, numa mesa de mercado público de Lisboa.

7 Alguns conectivos irão aparecer insistentemente em itálico ao longo deste ensaio: ainda, através, com, como entre outras palavras. Desta maneira busco, com essa estratégia de escrita, não só dar destaque a algo importante no argumento, como também conectar coisas sem dicotomiza-las, criar durações que escapam da ideia do antes e depois, explicitar uma coisa operando como outra, não no lugar dela, mas através dela, num processo de metamorfose e indiferenciação.

${ }^{8}$ Doreen Massey diferencia o conceito de lugar do de espaço através de uma radicalização: enquanto no conceito de espaço as trajetórias são coetâneas, no de lugar elas estão associadas à copresença de uma constelação específica de trajetórias; um lugar, portanto, seria estabelecido pelas interconexões e desconexões entre essas trajetórias copresentes (que podem, inclusive, ter presenças globais) e não por algum parâmetro de localização, de extensão, de origem ou de identidade.

9 Trecho de entrevista concedida a mim, em 2015, numa tasquinha de Lisboa.

10 Nas palavras de Francisco Elinaldo Teixeira: "Habituamo-nos a tomar as noções de real e realidade como sinônimas ou numa transição quase imperceptível de uma para a outra. Mas no âmbito de vários pensamentos influentes no pós-guerra (Nietzsche, Heidegger, Blanchot, Lacan, Foucault, Deleuze), tornou-se crucial a sua distinção [...]; houve uma repartição entre aquilo que contorna e comporta a realidade (o concreto, o dado, o empírico, o conhecido, o imaginado, tudo o que pode servir de matéria para a representação) e o que a excede, desafia, problematiza, que ela não comporta e que está fora dela - o real” (2012, p. 204).

${ }^{11}$ Nesse sentido, penso o cinema realizado por João Salaviza como arte, como aquilo que busca e tem potência para tornar sensível o antes insensível, considerando esse antes insensível não como algo inexistente, mas sim existente como excesso do real sensível, como algo virtualmente possível de tornar-se sensível.

$12 \mathrm{O}$ sentido da palavra estilo neste ensaio é aquele apresentado e discutido por Ana Godinho (2007). A partir dos escritos de Gilles Deleuze, essa autora aponta que “o estilo não é uma criação psicológica individual, particular, uma construção, uma 'maneira' (de ordenar frases, sons, matérias de expressão de qualquer espécie) ou uma 'forma' (pessoal) de um conteúdo (a 'forma' de uma escrita, por exemplo). [...] O estilo é o modo como as matérias de expressão se organizam para exprimirem o mundo” (p. 36-7), sendo, portanto, antes uma "passagem” pela qual o mundo expressase através do artista que uma "opção deliberada" desse último para expressar algo atinente a ele próprio. É nesse sentido que o estilo "não é uma organização reflectida, nem uma estrutura significante qualquer, nem ainda, uma inspiração espontânea [mas sim] determina uma posição, ajusta uma marca, incarna e faz devir as matérias. Dirige-se ao novo, o novo no pensamento, no modo de ver e entender e experimentar" (p. 43), estabelecendo assim uma singularidade que se dá no encontro com essas matérias de expressão do mundo, as quais, por se organizarem assim pela primeira vez, compõem "uma heterogeneidade que 
faz a diferença” (p. 43). De alguma forma, pode-se dizer que há, inclusive, uma sintonia entre o sentido da palavra estilo nos escritos de Ana Godinho e a fala de Salaviza na entrevista a mim concedida: "eu quero fazer filmes para poder ver mais, portanto me sinto um observador e não alguém que tem algo a dizer".

${ }^{13}$ Se o devir pode ser associado à ideia de simples abertura para o futuro (podendo esse ser previsto ou não, direcionado ou não), prefiro pensar o devir à maneira de Gilles Deleuze: “devir não é atingir uma forma (identificação, imitação, Mimese), mas encontrar uma zona de vizinhança, de indiscernibilidade ou de indiferenciação" (1997, p.11) que faz emergir algo da ordem do imprevisto, do não-preexistente: “o devir está sempre 'entre’ ou 'no meio"' (Deleuze, 1997, p.12). Portanto, devir não se vincula a um futuro previsto ou identificável, mas àquilo que está em metamorfose. ${ }_{14}$ Trecho de entrevista concedida à pesquisadora Helena Pires, em 2014, numa mesa de mercado público de Lisboa. O destaque é meu.

15 Mais à frente neste mesmo texto, outros sentidos se dobrarão sobre esse verbo.

16 Trecho de entrevista concedida a mim, em 2015, numa tasquinha de Lisboa.

17 Trecho de entrevista concedida a mim, em 2015, numa tasquinha de Lisboa.

18 "Eu acho que essa presença da cidade e o plano vibrar pra fora, explodir, transbordar pra fora do quadro... portanto ser um fluxo... o fora de campo invade ao mesmo tempo que o plano se tenta expandir. Isso tem a ver com a relação com a realidade, obviamente" (João Salaviza). Trecho de entrevista concedida a mim, em 2015, numa tasquinha de Lisboa.

19 É nesse sentido que os jovens personagens de Salaviza me parecem aglutinadores de boas pistas para um modo jovem de experimentar o espaço urbano contemporâneo, tendo a deriva aleatória uma certa "força iniciática", de transformação enquanto entrega, a que se pode chamar de "fisicalidade do encontro": inconscientemente os personagens tem que andar - são forçados a isso para poder encontrar algo no espaço público que os afetará e, talvez, lhes dará pistas para viver nesse mundo ou naquela situação singular da qual eles fazem parte.

${ }^{20}$ Trecho de entrevista concedida a mim, em 2015, numa tasquinha de Lisboa.

${ }^{21}$ João Salaviza sempre se refere à cidade como um corpo vivo.

22 Trecho de entrevista concedida a mim, em 2015, numa tasquinha de Lisboa. Todos os destaques são meus.

23 Trecho de entrevista concedida a mim, em 2015, numa tasquinha de Lisboa. Todos os destaques em itálico e em negrito são meus.

${ }^{24}$ Cabe lembrar a dificuldade que teve o diretor em selecionar um jovem para protagonizar o personagem Rafa. Numa conversa realizada em Braga com estudantes da Universidade do Minho, em 2015, João Salaviza relata que entrevistaram muitos jovens e não conseguiam selecionar nenhum. O jovem que trabalha no filme foi encontrado por acaso numa feira popular, tendo sido um tanto difícil convencê-lo a participar, desconfiado que estava quando foi abordado pela equipe. $\mathrm{O}$ cineasta procurava um jovem que tivesse em "fase de transformação", mas nem mesmo ele sabia exatamente o quê procurava para além dessa característica mais geral, mas finalizou dizendo que, de alguma forma, sabia que esse quêe encontrava-se também no corpo físico do jovem que viesse a protagonizar Rafa.

25 Trecho de entrevista concedida a mim, em 2015 , numa tasquinha de Lisboa. O destaque é meu.

${ }^{26}$ A intimidade sendo o real que devém filme. 
27 Trecho de entrevista concedida a mim, em 2015, numa tasquinha de Lisboa. O destaque é meu.

${ }^{28}$ Ver nota 21.

29 Trecho de entrevista concedida a mim, em 2015, numa tasquinha de Lisboa.

30 Trecho de entrevista concedida a mim, em 2015, numa tasquinha de Lisboa. O destaque é meu. Em um trecho da entrevista concedida à pesquisadora Helena Pires, Salaviza diz: "não me interessa nada esta noção estática, esta representação estática do espaço”.

31 Trecho de entrevista concedida a mim, em 2015, numa tasquinha de Lisboa. O destaque é meu.

32 "Precisamente porque es la esfera de la yuxtaposición potencial de los distintos relatos, del forjamiento de relaciones nuevas, la espacialidad es tambien una fuente para la producción de nuevas trayectorias, nuevas historias. Es una fuente de producción de espacios nuevos, identidades nuevas, relaciones y diferencias nuevas.” (Massey, 1999, p.174-175 - grifos do original)

\section{REFERÊNCIAS BIBLIOGRÁFICAS}

ALMEIDA, M. J. Imagens e sons - A nova cultura oral. São Paulo: Cortez, 1994.

DELEuZE, G. Crítica e clínica. São Paulo: Editora 34, 1997.
DELEUZE, G. O esgotado. In: Deleuze, G. Sobre o teatro: Um manifesto de menos; $O$ esgotado. Rio deJaneiro: Zahar, 2010.

GODINHO, A. Linhas do estilo - estética e ontologia em Gilles Deleuze. Lisboa: Relógio D’água, 2007.

MASSEY, D. La filosofía e la política de la espacialidad: algunas consideraciones (1999). In: Albet, A.; Benach, N. (orgs). Doreen Massey - Un sentido global del lugar. Barcelona: Icaria Editorial, 2012.

MASSEY, D. (2008) Pelo espaço - uma nova política da espacialidade. Rio de Janeiro: Bertrand Brasil, 2008.

OLIVEIRA Jr, W. M. As geografias menores nas obras em vídeo de artistas contemporâneos. In: Anais do XIV Encontro Ibérico de Geografia. Departamento de Geografia/Universidade do Minho: Guimarães, 2014.

TEIXEIRA, F. E. Cinemas "não narrativos": experimental e documentário - passagens. São Paulo: Alameda, 2012.

VILELA, E. Silêncios Tangíveis - corpo, resistência e testemunho nos espaços contemporâneos de abandono. Porto: Edições Afrontamento, 2010.

\section{FILMOGRAFIA}

Salaviza, J. Arena (filme). Portugal. 2009.

Salaviza, J. Cerro Negro (filme). Portugal. 2011.

Salaviza, J. Rafa (filme). Portugal. 2012. 
COUCH IN THE SQUARE: THE SPACE AS ENCOUNTER IN JOAO SALAVIZA'S CINEMA

abStraCt: FrOM the PERSPECTIVE OF CINEMA AS ENCOUNTER OF the PORTUGUESE FILMMAKER JOÃO SALAVIZA, APPROXIMATIONS WERE TESTED BETWEEN THIS STYLE OF CINEMA AND FILM MAKING WITH THE THOUGHT OF GEOGRAPHER DOREEN MASSEY AND SO INDICATING "NEW POSSIBLES" WAYS OF DEALING WITH THE CONNECTION BETWEEN IMAGES AND GEOGRAPHY, WHILE CLUES TO ANSWER THE QUESTIONS ARE PROPOSED: WHAT WOULD THIS STYLE OF FILM MAKING TELL US ABOUT OTHER POSSIBLE RELATIONS BETWEEN IMAGES AND GEOGRAPHY? WOULD THIS STYLE HAVE POTENCY TO CREATE IMAGES WHICH WOULD ACT AS "MINOR GEOGRAPHIES" CAPABLE OF CAUSING SMALL ERASURES IN GEOGRAPHICAL THOUGHT IN GENERAL OR IN THE RELATIONS that IT ESTABLISHES WITH THE IMAGES, ESPECIALLY WHEN THE LATTER ARE MEANT ONLY AS A SPATIAL REPRESENTATION?

KEYWORDS: CINEMA, SMALLER GEOGRAPHIES, ENCOUNTER, JOAO SALAVIZA, DOREEN MASSEY.

\section{El SOFÁ EN LA PLAZA: EL ESPACIO COMO ENCUENTRO EN EL CINE DE JOÃO SALAVIZA}

RESUMEM: DESDE LA PERSPECTIVA DEL CINE COMO ENCUENTRO DEL REALIZAdOR PORTUGUÉS JOÃO SALAVIZA, SE ENSAYAN APROXIMACIONES ENTRE ESTE ESTILO DE HACER CINE Y PELICCULAS Y EL PENSAMIENTO DE LA GEÓGRAFA DOREEN MASSEY. SE APUNTAN "NUEVOS POSIBLES" MODOS DE ABORDAR la RELACIÓN ENTRE las IMÁGENES Y LA GEOGRAFía PROPONIENDO CLAVES PARA RESPONDER a las SIGUIENTES PREgUNTAS: ¿QUÉ APORTA ESTE ESTILO DE HACER CINE A OTRAS POSIBLES 
RELACIONES ENTRE LAS IMÁGENES Y LA GEOGRAFía? ¿EXISTIRÍAN POTENCIAS DE CREACIÓN DE IMÁGENES EN ESTE ESTILO

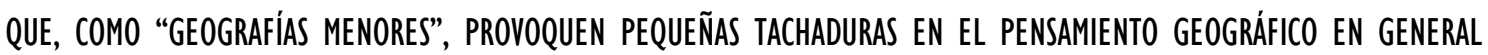
0 EN SUS RELACIONES CON LAS IMÁGENES, PARTICULARMENTE CUANDO ESTAS ÚlTIMAS SON CONCEBIDAS SÓLO COMO UNA REPRESENTACIÓN ESPACIAL?

Palabras ClaVE: CINE, GEOGRaFías MENORES, ENCUENTRO, JOÃO SALAVIZA, DOREEN MASSEY. 